\title{
Refractory Soft Tissue Sarcoma
}

National Cancer Institute

\section{Source}

National Cancer Institute. Refractory Soft Tissue Sarcoma. NCI Thesaurus. Code C139001.

A soft tissue sarcoma that does not respond to treatment. 